Correspondence

A. Ventosa ventosa@us.es

\section{Halopiger xanaduensis gen. nov., sp. nov., an extremely halophilic archaeon isolated from saline Lake Shangmatala in Inner Mongolia, China}

\author{
M. C. Gutiérrez, ${ }^{1}$ A. M. Castillo, ${ }^{1}$ M. Kamekura, ${ }^{2}$ Y. Xue, ${ }^{3}$ Y. Ma, ${ }^{3}$ \\ D. A. Cowan, ${ }^{4}$ B. E. Jones, ${ }^{5}$ W. D. Grant ${ }^{6}$ and A. Ventosa ${ }^{1}$
}

\begin{abstract}
${ }^{1}$ Department of Microbiology and Parasitology, Faculty of Pharmacy, University of Sevilla, 41012 Sevilla, Spain

${ }^{2}$ Noda Institute for Scientific Research, 399 Noda, Noda-shi, Chiba-ken 278-0037, Japan

${ }^{3}$ State Key Laboratory of Microbial Resources, Institute of Microbiology, Chinese Academy of Sciences, 100080 Beijing, China

${ }^{4}$ Department of Biotechnology, University of the Western Cape, Bellville 7535, Cape Town, South Africa

${ }^{5}$ Genencor International BV, Archimedesweg 30, 2333 CN Leiden, The Netherlands

${ }^{6}$ Department of Infection, Immunity and Inflammation, University of Leicester, Leicester LE1 9HN, UK
\end{abstract}

Strain $\mathrm{SH}-6^{\top}$ was isolated from the sediment of Lake Shangmatala, a saline lake in Inner Mongolia (China). Cells were pleomorphic. The organism was neutrophilic and required at least $2.5 \mathrm{M}$

$(15 \%) \mathrm{NaCl}$, but not $\mathrm{MgCl}_{2}$, for growth; optimal growth occurred at $4.3 \mathrm{M}(25 \%) \mathrm{NaCl}$. The $\mathrm{G}+\mathrm{C}$ content of its DNA was $63.1 \mathrm{~mol} \%$. 16S rRNA gene sequence analysis revealed that strain $\mathrm{SH}-6^{\top}$ is a member of the family Halobacteriaceae, but there was a low level of similarity with other members of this family. Highest sequence similarity (94.6\%) was obtained with the 16S rRNA genes of the type strains of Natronolimnobius innermongolicus and Natronolimnobius baerhuensis. Polar lipid analyses revealed that strain $\mathrm{SH}-6^{\top}$ contains phosphatidylglycerol and phosphatidylglyceromethylphosphate, derived from both $\mathrm{C}_{20} \mathrm{C}_{20}$ and $\mathrm{C}_{20} \mathrm{C}_{25}$ glycerol diethers together with the glycolipid $\mathrm{S}_{2}$-DGD-1. On the basis of the data obtained, the new isolate could not be classified in any recognized genus. Strain $\mathrm{SH}-6^{\top}$ is thus considered to represent a novel species in a new genus within the family Halobacteriaceae, order Halobacteriales, for which the name Halopiger xanaduensis gen. nov., sp. nov. is proposed. The type strain of Halopiger xanaduensis is $\mathrm{SH}-6^{\top}$ $\left(=\mathrm{CECT} 7173^{\top}=\right.$ CGMCC $\left.1.6379^{\top}=\mathrm{JCM} 14033^{\mathrm{T}}\right)$.
The haloarchaea constitute a large group of extremely halophilic, aerobic archaea that are placed in the order Halobacteriales, family Halobacteriaceae (Grant et al., 2001). Classically, they were easily differentiated microscopically as rods or cocci that were, respectively, included within the genera Halobacterium or Halococcus (Gibbons, 1974). In recent years, the numbers of halobacterial genera and species have increased due to the use of different isolation media and culture conditions, combined with the study of a wide variety of hypersaline environments. The extremely halophilic archaea are the dominant microbial populations of

The GenBank/EMBL/DDBJ accession number for the 16S rRNA gene sequence of strain $\mathrm{SH}-6^{\top}$ is $\mathrm{AM} 268114$.

A thin-layer chromatograph of the polar lipids of strain $\mathrm{SH}-6^{\top}$ and related haloarchaea is available as a supplementary figure with the online version of this paper. hypersaline environments (Ventosa, 2006). The current classification of halophilic archaea is based on three kinds of data: phenotypic features, chemical data (polar lipid composition) and genetic data (16S rRNA gene sequence information and DNA-DNA hybridization) (Oren et al., 1997; Grant et al., 2001). At the time of writing, the aerobic, extremely halophilic archaea are classified within 22 different genera with a large number of species. These genera are Halalkalicoccus, Haloarcula, Halobacterium, Halobaculum, Halobiforma, Halococcus, Haloferax, Halogeometricum, Halomicrobium, Halorhabdus, Halorubrum, Halosimplex, Halostagnicola, Haloterrigena, Halovivax, Natrialba, Natrinema, Natronobacterium, Natronococcus, Natronolimnobius, Natronomonas and Natronorubrum (Tindall et al., 1984; Torreblanca et al., 1986; Oren et al., 1995, 2002; Kamekura \& Dyall-Smith, 1995; Kamekura et al., 1997; McGenity et al., 1998; Montalvo-Rodriguez et al., 1998; Ventosa et al., 1999; 
Xu et al., 1999; Wainø et al., 2000; Grant, 2001a, b; Hezayen et al., 2002; Vreeland et al., 2002; Itoh et al., 2005; Xue et al., 2005; Castillo et al., 2006a, b).

Here we describe a halophilic archaeal strain, designated SH $-6^{\mathrm{T}}$, which was isolated from Lake Shangmatala, located in Inner Mongolia Autonomous Region, China. Preliminary 16S rRNA gene sequence comparisons indicated that the isolate was a member of the family Halobacteriaceae. The aim of the present work was to determine the exact taxonomic position of strain $\mathrm{SH}-6^{\mathrm{T}}$ by using a polyphasic taxonomic characterization that combined phenotypic, chemotaxonomic and phylogenetic analyses.

Strain $\mathrm{SH}-6^{\mathrm{T}}$ was isolated from a sediment sample from Shangmatala salt lake $\left(43^{\circ} 12^{\prime} \mathrm{N} 114^{\circ} 01^{\prime} \mathrm{E}\right)$ by enrichment in liquid medium after 15 days incubation and subsequent plating of the enriched culture until purity was obtained on the same medium but with $2 \%$ agar added. The medium contained (per litre distilled water): $174 \mathrm{~g} \mathrm{NaCl}, 30 \mathrm{~g}$ $\mathrm{MgCl}_{2} .6 \mathrm{H}_{2} \mathrm{O}, 45.4 \mathrm{~g} \mathrm{MgSO}_{4} .7 \mathrm{H}_{2} \mathrm{O}, 0.8 \mathrm{~g} \mathrm{CaCl}_{2}, 4.5 \mathrm{~g} \mathrm{KCl}$, $0.16 \mathrm{~g} \mathrm{NaHCO}_{3}, 0.5 \mathrm{~g} \mathrm{NaBr}$ and 5 g yeast extract; the $\mathrm{pH}$ was adjusted to 8 with $1 \mathrm{M} \mathrm{NaOH}$ solution. At the time of sampling, the water in the lake had a salinity of $16.7 \%$, a temperature of $21.8^{\circ} \mathrm{C}$ and a pH of 8.5. Strain SH- $6^{\mathrm{T}}$ grew at a temperature range of $28-45^{\circ} \mathrm{C}$ (optimum $37^{\circ} \mathrm{C}$ ) and a $\mathrm{pH}$ range of 6.0-11 (optimum $\mathrm{pH}$ 7.5-8). Routine cultivation was conducted at $37^{\circ} \mathrm{C}$ and $\mathrm{pH}$ 8. Growth ranges and optima for $\mathrm{NaCl}$ and $\mathrm{MgCl}_{2}$ were determined by using the growth medium containing various concentrations of $\mathrm{NaCl}$ (0.9-5.2 M) and $\mathrm{MgCl}_{2}(0-0.5 \mathrm{M})$, respectively. Strain $\mathrm{SH}-6^{\mathrm{T}}$ was capable of growing over a wide range of $\mathrm{NaCl}$ concentrations: $2.5 \mathrm{M}(15 \%)$ to $5 \mathrm{M}(30 \%)$. It grew optimally in the presence of $4.3 \mathrm{M}(25 \%) \mathrm{NaCl}$, as has been shown for most extremely halophilic archaea. $\mathrm{MgCl}_{2}$ was not required for growth.

Phenotypic tests were performed according to the proposed minimal standards for the description of new taxa in the order Halobacteriales (Oren et al., 1997). Cell motility and morphology were observed under a phase-contrast light microscope (Olympus BX41) from an early exponential phase liquid culture. Cells of strain $\mathrm{SH}-6^{\mathrm{T}}$ were non-motile and pleomorphic, although long rod-shaped cells were most common (Fig. 1). Rod-shaped cells were 3-13 $\times 0.5-1 \mu \mathrm{m}$ in size. Colony morphology was observed on agar medium under optimal growth conditions after incubation at $37^{\circ} \mathrm{C}$ for 10 days. Anaerobic growth was tested in the presence of $5 \mathrm{~g}$ nitrate or L-arginine $\mathrm{l}^{-1}$ in filled, stoppered tubes. Tests for catalase and oxidase activities and hydrolysis of starch, casein, gelatin and Tween 80 were performed as described by Gonzalez et al. (1978). Nitrate reduction, $\mathrm{H}_{2} \mathrm{~S}$ formation, indole formation and the utilization of sugars, alcohols, amino acids and organic acids were carried out as described by Oren et al. (1997). Antibiotic sensitivity tests were performed by spreading bacterial suspensions on culture plates and applying discs impregnated with the following antibiotics (amounts in parentheses): ampicillin $(10 \mu \mathrm{g})$, bacitracin $(10 \mathrm{U})$, cephalothin $(30 \mu \mathrm{g})$, chloramphenicol

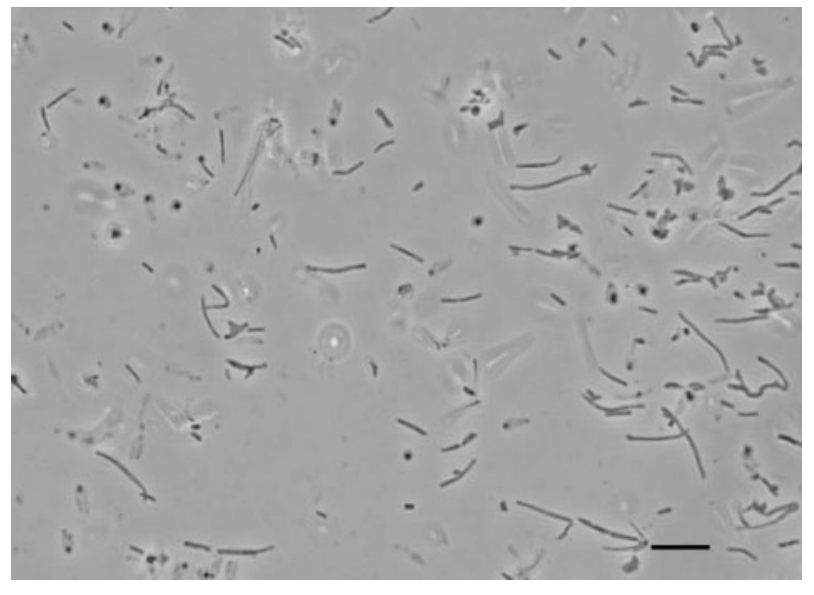

Fig. 1. Phase-contrast micrograph of cells of strain $\mathrm{SH}-6^{\top}$ grown in liquid medium under optimum conditions. Bar, $10 \mu \mathrm{m}$.

(30 $\mu \mathrm{g})$, erythromycin $(15 \mu \mathrm{g})$, gentamicin $(10 \mu \mathrm{g})$, kanamycin $(30 \mu \mathrm{g})$, nalidixic acid $(30 \mu \mathrm{g})$, neomycin $(10 \mu \mathrm{g})$, novobiocin $(30 \mu \mathrm{g})$, penicillin $\mathrm{G}(10 \mathrm{U})$, rifampicin $(30 \mu \mathrm{g})$, polymyxin (300 $\mathrm{U})$, streptomycin $(10 \mu \mathrm{g})$, sulfamethoxazole $(25 \mu \mathrm{g})$, tetracycline $(30 \mu \mathrm{g})$ and vancomycin $(30 \mu \mathrm{g})$. The physiological and biochemical characteristics and antibiotic susceptibility of strain $\mathrm{SH}-6^{\mathrm{T}}$ are given in the species description below.

Polar lipids were extracted with chloroform/methanol as described by Kamekura (1993). TLC was performed by using Merck HPTLC silica gel 60 plates (Art. 5641) in the solvent system, which comprised chloroform/methanol/ acetic acid/water ( $85: 22.5: 10: 4$, by vol.). Glycolipids were detected as purple spots by spraying with $0.5 \% \alpha$-naphthol in methanol/water $(1: 1)$ and then with sulfuric acid/ethanol $(1: 1)$, followed by heating at $160^{\circ} \mathrm{C}$. TLC of polar lipids (see Supplementary Fig. S1 available in IJSEM Online) suggested that strain $\mathrm{SH}-6^{\mathrm{T}}$ contained phosphatidylglycerol and phosphatidylglyceromethylphosphate derived from both $\mathrm{C}_{20} \mathrm{C}_{20}$ and $\mathrm{C}_{20} \mathrm{C}_{25}$ glycerol diethers as shown from the two spots (Xin et al., 2000). The glycolipid $\mathrm{S}_{2}$-DGD-1 was also detected.

Chromosomal DNA of strain $\mathrm{SH}-6^{\mathrm{T}}$ was isolated and purified according to the methods described by Wilson (1987) and Marmur (1961). The G+C content of the genomic DNA was determined from the mid-point $\left(T_{\mathrm{m}}\right)$ of the thermal denaturation profile (Marmur \& Doty, 1962) by using the equation of Owen \& Hill (1979). The DNA G + C content of strain SH- $6^{\mathrm{T}}$ was $63.1 \mathrm{~mol} \%$. The $16 \mathrm{~S}$ rRNA gene of strain $\mathrm{SH}-6^{\mathrm{T}}$ was amplified by PCR by using three universal primers as described by Lopez-Garcia et al. (2001) and Arahal et al. (1996) and the near-full-length nucleotide sequence (approximately $1400 \mathrm{bp}$ ) was determined. The ARB software package (Ludwig et al., 2004) was used for $16 \mathrm{~S}$ rRNA gene sequence analysis. Base-frequency filters were applied in the sequence comparison analysis and the effects 
on the results were evaluated. Comparison of the sequence with members of the family Halobacteriaceae based on the neighbour-joining method (Saitou \& Nei, 1987) revealed that strain $\mathrm{SH}-6^{\mathrm{T}}$ was distantly related to the other haloarchaeal genera investigated (Fig. 2). The type strains of Natronolimnobius innermongolicus and Natronolimnobius baerhuensis were shown to be the closest relatives of strain SH $-6^{\mathrm{T}}$, having a $16 \mathrm{~S}$ rRNA sequence similarity value of $94.6 \%$. However, the similarity values were almost identical for several aerobic, extremely halophilic members of the Archaea representing various genera, e.g. the type strains of Natrialba aegyptiaca (94.5\%), Natronorubrum tibetense $(93.5 \%)$ and Natronococcus occultus (94.1\%). Similar topologies were obtained when other treeing methods (maximum-parsimony and maximum-likelihood) were used. In consequence, it was concluded that strain SH-6 ${ }^{\mathrm{T}}$ formed a new distinct branch related to Natronolimnobius innermongolicus and Natronolimnobius baerhuensis. The phenotypic characteristics of these two species of the genus Natronolimnobius are very different from those of strain SH- $6^{\mathrm{T}}$, i.e. their morphology (Fig. 1), optimum salinity and $\mathrm{pH}$ for growth, indole production, their ability to use carbon sources such as D-raffinose, D-arabinose, glycerol, fumarate and L-glutamate and their susceptibility to antibiotics (Table 1). Additionally, members of Natronolimnobius do not have detectable amounts of glycolipids, while strain SH- ${ }^{\mathrm{T}}$ contains the glycolipid $\mathrm{S}_{2}$-DGD-1. It is worth noting that polar lipid composition has been found to be an excellent taxonomic marker for the delineation of haloarchaeal genera (Oren et al., 1997; Grant et al., 2001).

The phenotypic, polar lipid composition and phylogenetic data (based on 16S rRNA gene sequence comparisons) indicate that strain $\mathrm{SH}-6^{\mathrm{T}}$ represents a novel species in a new genus within the haloarchaea, for which we propose the name Halopiger xanaduensis gen. nov., sp. nov. Table 1 details the characteristics that differentiate the new genus from other related haloarchaeal genera.

\section{Description of Halopiger gen. nov.}

Halopiger (Ha.lo.pi'ger. Gr. n. hals, halos salt; L. masc. adj. piger lazy; N.L. masc. n. Halopiger lazy halophile, referring to the slow growth under laboratory conditions).

Gram-negative. Cells are pleomorphic although most are long rods. Colonies are red pigmented. Strictly aerobic; oxygen is used as the terminal electron acceptor. Growth occurs at $\mathrm{pH} 6.0-11.0$, at $28-45^{\circ} \mathrm{C}$ and at $2.5-5.0 \mathrm{M}$ (15-30\%) NaCl. Optimal growth occurs at $\mathrm{pH} 7.5-8.0$, $37^{\circ} \mathrm{C}$ and $4.3 \mathrm{M}(25 \%) \mathrm{NaCl}$. The DNA G $+\mathrm{C}$ content of the only species in the genus is $63.1 \mathrm{~mol} \%$ ( $T_{\mathrm{m}}$ method). Polar lipids include phosphatidylglycerol and phosphatidylglyceromethylphosphate derived from both $\mathrm{C}_{20} \mathrm{C}_{20}$ and $\mathrm{C}_{20} \mathrm{C}_{25}$ glycerol diethers and the glycolipid $\mathrm{S}_{2}$-DGD-1. Isolated from salt lakes. Phylogenetically affiliated to the Halobacteriaceae. The type species is Halopiger xanaduensis. Recommended three-letter abbreviation of the genus: Hpg.

\section{Description of Halopiger xanaduensis sp. nov.}

Halopiger xanaduensis (xa.na.du.en'sis. N.L. masc. adj. xanaduensis referring to Xanadu, the lost city of Kublai Khan, located in Inner Mongolia, from where the type strain was isolated).

Exhibits the following properties in addition to those given in the genus description. Cells are $0.5-1.0 \mu \mathrm{m}$ wide and $3.0-13.0 \mu \mathrm{m}$ long (Fig. 1). Colonies are circular, $1-2 \mathrm{~mm}$ in diameter after incubation for 10 days at $37^{\circ} \mathrm{C}$. Extremely halophilic. Cells lyse in water. Magnesium is not required. Growth does not occur above $45^{\circ} \mathrm{C}$. Amino acids are not required for growth. Catalase- and oxidase-positive. Anaerobic growth with arginine does not occur. Production of indole and methyl red, Voges-Proskauer and Simmons' citrate tests are negative. $\mathrm{H}_{2} \mathrm{~S}$ is not produced from cysteine. Acid is produced from D-arabinose, D-glucose and D-xylose, but not from D-fructose, D-galactose, glycerol, lactose,

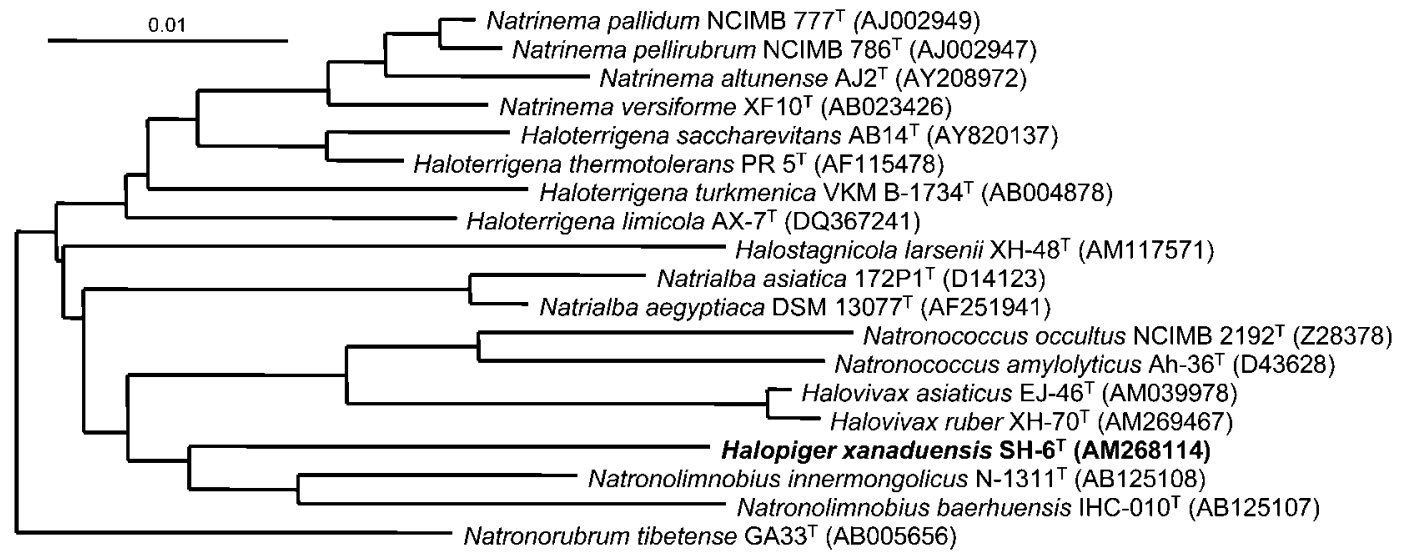

Fig. 2. Neighbour-joining phylogenetic tree based on $16 \mathrm{~S}$ rRNA gene sequence comparisons, showing the position of strain $\mathrm{SH}-6^{\top}$ and some other related haloarchaeal species. Accession numbers of the sequences used in this study are shown in parentheses after the strain designation. Bar, $1 \%$ sequence divergence. 
Table 1. Characteristics that distinguish strain $\mathrm{SH}-6^{\top}$ from members of other related haloarchaeal genera

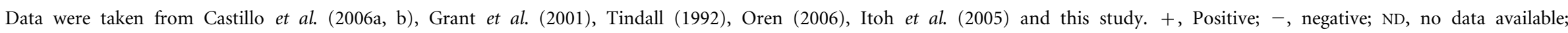
$\mathrm{v}$, variable.

\begin{tabular}{|c|c|c|c|c|c|c|c|c|}
\hline Characteristic & Strain $\mathrm{SH}-6^{\mathrm{T}}$ & Natronolimnobius & Natrialba & Natronococcus & Natronobacterium & Natrinema & Halostagnicola & Halovivax \\
\hline Morphology & $\begin{array}{c}\text { Rods/pleomorphic } \\
\text { rods }\end{array}$ & $\begin{array}{c}\text { Rods/pleomorphic } \\
\text { rods }\end{array}$ & Rods & Cocci & Rods & $\begin{array}{c}\text { Rods/pleomorphic } \\
\text { rods }\end{array}$ & $\begin{array}{c}\text { Rods/pleomorphic } \\
\text { rods }\end{array}$ & $\begin{array}{c}\text { Rods/pleomorphic } \\
\text { rods }\end{array}$ \\
\hline Cell size $(\mu \mathrm{m})$ & $3-13 \times 0.5-1$ & $1.5-6 \times 0.5-0.6$ & $0.5-1 \times 1-5$ & $1-2$ & $0.5-0.7 \times 10-15$ & $0.6-1 \times 1-6$ & $0.5-1 \times 1-3$ & $0.4-0.5 \times 4-5$ \\
\hline Pigmentation & Red & Red & White/red & Red & Red & $\begin{array}{l}\text { Light red to pale } \\
\text { orange }\end{array}$ & Pink & Pale pink \\
\hline $\mathrm{NaCl}$ optimum $(\mathrm{M})$ & 4.3 & 3.4 & $3.5-4$ & $2.5-3.8$ & 3.0 & $3.4-4.3$ & 3.4 & 3.4 \\
\hline $\mathrm{NaCl}$ range $(\mathrm{M})$ & $2.5-5.0$ & $1.7-4.3$ & $2.0-5.2$ & $1.4-5.2$ & $2.0-5.2$ & $\mathrm{ND}$ & $2.5-5.0$ & $2.5-4.3$ \\
\hline pH optimum & 8.0 & 9 & $6.6-9.5$ & $9.0-9.5$ & 9.5 & $7.2-7.6$ & $7.0-8.0$ & $7.0-7.5$ \\
\hline Temperature optimum $\left({ }^{\circ} \mathrm{C}\right)$ & 37 & $37-45$ & $35-40$ & $35-45$ & 37 & $37-40$ & 37 & 37 \\
\hline Nitrite from nitrate & - & $\mathrm{V}$ & + & + & - & + & + & - \\
\hline \multicolumn{9}{|l|}{ Hydrolysis of: } \\
\hline Starch & - & - & $\mathrm{V}$ & $\mathrm{V}$ & - & - & + & - \\
\hline Gelatin & + & $\mathrm{V}$ & $+/ \mathrm{ND}$ & $\mathrm{V}$ & + & + & - & + \\
\hline Casein & - & - & $+/ \mathrm{ND}$ & ND & ND & ND & - & + \\
\hline Tween 80 & + & $\mathrm{V}$ & ND & ND & ND & ND & - & + \\
\hline DNA & - & ND & ND & ND & ND & $\mathrm{ND}$ & - & - \\
\hline Indole production & - & + & ND & ND & ND & $\mathrm{V}$ & + & - \\
\hline Urease & + & ND & ND & ND & ND & ND & - & + \\
\hline $\mathrm{H}_{2} \mathrm{~S}$ production & - & $\mathrm{V}$ & $\mathrm{v}$ & ND & $\mathrm{v}$ & $\mathrm{V}$ & + & - \\
\hline Major glycolipids & $\mathrm{S}_{2}$-DGD-1 & - & $-/ S_{2}-\mathrm{DGD}-1$ & - & - & Unidentified & Unidentified & Unidentified \\
\hline DNA G $+C$ content $(\mathrm{mol} \%)$ & 63.1 & $59-63$ & $60.0-63.1$ & $63.5-64$ & 65.0 & 69.9 & 61.0 & 60.3 \\
\hline
\end{tabular}


maltose, D-mannitol, sucrose or D-trehalose. Arginine dihydrolase, lysine decarboxylase and ornithine decarboxylase are not produced. Urea, Tween 80 , gelatin and aesculin are hydrolysed, whereas starch, casein, DNA and phosphatase are not. Nitrate and nitrite are reduced with gas production. The following substrates are utilized as sole carbon and energy sources: D-galactose, D-glucose, Dxylose, L-asparagine, L-serine, acetate and L-glutamate. No growth on D-arabinose, D-fructose, lactose, maltose, Dmannose, D-raffinose, D-ribose, starch, D-trehalose, glycerol, D-sorbitol, D-mannitol, glycine, isoleucine, L-lysine, Lthreonine, fumarate, malate, propionate or succinate. Susceptible to bacitracin $(10 \mathrm{U})$, novobiocin $(30 \mu \mathrm{g})$ and sulfamethoxazole $(25 \mu \mathrm{g})$. Resistant to ampicillin $(10 \mu \mathrm{g})$, cephalothin $(30 \mu \mathrm{g})$, chloramphenicol $(30 \mu \mathrm{g})$, erythromycin $(15 \mu \mathrm{g})$, gentamicin $(10 \mu \mathrm{g})$, kanamycin $(30 \mu \mathrm{g})$, nalidixic acid $(30 \mu \mathrm{g})$, neomycin $(10 \mu \mathrm{g})$, penicillin $\mathrm{G}$ $(10 \mathrm{U})$, rifampicin $(30 \mu \mathrm{g})$, polymyxin $(300 \mathrm{U})$, streptomycin $(10 \mu \mathrm{g})$, tetracycline $(30 \mu \mathrm{g})$ and vancomycin $(30 \mu \mathrm{g})$. The $\mathrm{G}+\mathrm{C}$ content of the DNA is $63.1 \mathrm{~mol} \%\left(T_{\mathrm{m}}\right)$.

The type strain, SH- $6^{\mathrm{T}} \quad\left(=\mathrm{CECT} \quad 7173^{\mathrm{T}}=\mathrm{CGMCC}\right.$ $1.6379^{\mathrm{T}}=\mathrm{JCM} 14033^{\mathrm{T}}$ ), was isolated from Shangmatala salt lake, Inner Mongolia, China.

\section{Acknowledgements}

This study was supported by grants from the Quality of Life and Management of Living Resources Programme of the European Commission (Project 'Multigenome Access Technology for Industrial Catalysts', QLK3CT-2002-01972), Spanish Ministerio de Educación y Ciencia (BMC200301344 and BIO2006-06927) and the Junta de Andalucia.

\section{References}

Arahal, D. R., Dewhirst, F. E., Paster, B. J., Volcani, B. E. \& Ventosa, A. (1996). Phylogenetic analyses of some extremely halophilic archaea isolated from Dead Sea water, determined on the basis of their 16S rRNA sequences. Appl Environ Microbiol 62, 3779-3786.

Castillo, A. M., Gutiérrez, M. C., Kamekura, M., Ma, Y., Cowan, D. A., Jones, B. E., Grant, W. D. \& Ventosa, A. (2006a). Halovivax asiaticus gen. nov., sp. nov., a novel extremely halophilic archaeon isolated from Inner Mongolia, China. Int J Syst Evol Microbiol 56, 765-770.

Castillo, A. M., Gutiérrez, M. C., Kamekura, M., Ma, Y., Cowan, D. A., Jones, B. E., Grant, W. D. \& Ventosa, A. (2006b). Halostagnicola larsenii gen. nov., sp. nov., an extremely halophilic archaeon from a saline lake in Inner Mongolia, China. Int J Syst Evol Microbiol 56, 1515-1517.

Gibbons, N. E. (1974). Family V. Halobacteriaceae fam. nov. In Bergey's Manual of Determinative Bacteriology, 8th edn, pp. 269-273. Edited by R. E. Buchanan \& N. E. Gibbons. Baltimore: Williams \& Wilkins.

Gonzalez, C., Gutierrez, C. \& Ramírez, C. (1978). Halobacterium vallismortis sp. nov. An amylolytic and carbohydrate-metabolizing, extremely halophilic bacterium. Can J Microbiol 24, 710-715.

Grant, W. D. (2001a). Genus I. Halobacterium Elazari-Volcani 1957, $207,{ }^{\mathrm{AL}}$ emend. Larsen and Grant 1989, 2222. In Bergey's Manual of Systematic Bacteriology, 2nd edn, vol. 1, pp. 301-305. Edited by D. R. Boone, R. W. Castenholz \& G. M. Garrity. New York: Springer.

Grant, W. D. (2001b). Genus IV. Halococcus Schoop 1935a, $817^{\mathrm{AL}}$. In Bergey's Manual of Systematic Bacteriology, 2nd edn, vol. 1, pp. 311-314. Edited by D. R. Boone, R. W. Castenholz \& G. M. Garrity. New York: Springer.
Grant, W. D., Kamekura, M., McGenity, T. J. \& Ventosa, A. (2001). Order I. Halobacteriales Grant and Larsen 1989b, 495 vp (Effective publication: Grant and Larsen 1989a, 2216). In Bergey's Manual of Systematic Bacteriology, 2nd edn, vol. 1, pp. 294-299. Edited by D. R. Boone, R. W. Castenholz \& G. M. Garrity. New York: Springer.

Hezayen, F. F., Tindall, B. J., Steinbüchel, A. \& Rehm, B. H. A. (2002). Characterization of a novel halophilic archaeon, Halobiforma haloterrestris gen. nov., sp. nov., and transfer of Natronobacterium nitratireducens to Halobiforma nitratireducens comb. nov. Int J Syst Bacteriol 52, 2271-2280.

Itoh, T., Yamaguchi, T., Zhou, P. \& Takashina, T. (2005). Natronolimnobius baerhuensis gen. nov., sp. nov. and Natronolimnobius innermongolicus sp. nov., novel haloalkaliphilic archaea isolated from soda lakes in Inner Mongolia, China. Extremophiles 9, 111-116.

Kamekura, M. (1993). Lipids of extreme halophiles. In The Biology of Halophilic Bacteria, pp. 135-161. Edited by R. H. Vreeland \& L. I. Hochstein. Boca Raton, FL: CRC Press.

Kamekura, M. \& Dyall-Smith, M. L. (1995). Taxonomy of the family Halobacteriaceae and the description of two genera Halorubrobacterium and Natrialba. J Gen Appl Microbiol 41, 333-350.

Kamekura, M., Dyall-Smith, M. L., Upasani, V., Ventosa, A. \& Kates, M. (1997). Diversity of alkaliphilic halobacteria: proposals for transfer of Natronobacterium vacuolatum, Natronobacterium magadii, and Natronobacterium pharaonis to Halorubrum, Natrialba and Natronomonas gen. nov., respectively, as Halorubrum vacuolatum comb. nov., Natrialba magadii comb. nov., and Natronomonas pharaonis comb. nov., respectively. Int J Syst Bacteriol 47, 853-857.

Lopez-Garcia, P., Moreira, D., Lopez-Lopez, A. \& Rodríguez-Valera, F. (2001). A novel haloarchaeal-related lineage is widely distributed in deep oceanic regions. Environ Microbiol 3, 72-78.

Ludwig, W., Strunk, O., Westram, R., Richter, L., Meier, H., Yadhukumar, Buchner, A., Lai, T., Steppi, S. \& other authors (2004). ARB: a software environment for sequence data. Nucleic Acids Res 32, 1363-1371.

Marmur, J. (1961). A procedure for the isolation of deoxyribonucleic acid from microorganisms. J Mol Biol 3, 208-218.

Marmur, J. \& Doty, P. (1962). Determination of the base composition of deoxyribonucleic acid from its thermal denaturation temperature. J Mol Biol 5, 109-118.

McGenity, T. J., Gemmell, R. T. \& Grant, W. D. (1998). Proposal of a new halobacterial genus Natrinema gen. nov., with two species Natrinema pellirubrum nom. nov. and Natrinema pallidum nom. nov. Int J Syst Bacteriol 48, 1187-1196.

Montalvo-Rodriguez, R., Vreeland, R. H., Oren, A., Kessel, M., Betancourt, C. \& Lopez-Garriga, J. (1998). Halogeometricum borinquense gen. nov., sp. nov., a novel halophilic archaeon from Puerto Rico. Int J Syst Bacteriol 48, 1305-1312.

Oren, A. (2006). The order Halobacteriales. In The Prokaryotes: a Handbook on the Biology of Bacteria, 3rd edn, vol. 3, pp. 113-164. Edited by M. Dworkin, S. Falkow, E. Rosenberg, K.-H. Schleifer \& E. Stackebrandt. New York: Springer.

Oren, A., Gurevich, P., Gemmell, R. T. \& Teske, A. (1995). Halobaculum gomorrense gen. nov., sp. nov., a novel extremely halophilic archaeon from the Dead Sea. Int J Syst Bacteriol 45, 747-754.

Oren, A., Ventosa, A. \& Grant, W. D. (1997). Proposed minimal standards for description of new taxa in the order Halobacteriales. Int J Syst Bacteriol 47, 233-238.

Oren, A., Elevi, R., Watanabe, S., Ihara, K. \& Corcelli, A. (2002). Halomicrobium mukohataei gen. nov., comb. nov., and emended description of Halomicrobium mukohataei. Int J Syst Evol Microbiol 52, 1831-1835. 
Owen, R. J. \& Hill, L. R. (1979). The estimation of base compositions, base pairing and genome size of bacterial deoxyribonucleic acids. In Identification Methods for Microbiologists, 2nd edn, pp. 217-296. Edited by F. A. Skinner \& D. W. Lovelock. London: Academic Press.

Saitou, N. \& Nei, M. (1987). The neighbor-joining method: a new method for reconstructing phylogenetic trees. Mol Biol Evol 4, 406-425.

Tindall, B. J. (1992). The family Halobacteriaceae. In The Prokaryotes. A Handbook of Bacteria: Ecophysiology, Isolation, Identification, Applications, 2nd edn, vol. 1, pp. 768-808. Edited by A. Balows, H. G. Trüper, M. Dworkin, W. Harder \& K. H. Schleifer. New York: Springer.

Tindall, B. J., Ross, H. N. M. \& Grant, W. D. (1984). Natronobacterium gen. nov. and Natronococcus gen. nov., two new genera of haloalkaliphilic archaebacteria. Syst Appl Microbiol 5, 41-57.

Torreblanca, M., Rodriguez-Valera, F., Juez, G., Ventosa, A., Kamekura, M. \& Kates, M. (1986). Classification of non-alkaliphilic halobacteria based on numerical taxonomy and polar lipid composition and description of Haloarcula gen. nov. and Haloferax gen. nov. Syst Appl Microbiol 8, 89-99.

Ventosa, A. (2006). Unusual micro-organisms from unusual habitats: hypersaline environments. In Prokaryotic Diversity: Mechanisms and Significance (Society for General Microbiology Symposium no. 66), pp. 223-253. Edited by N. A. Logan, H. M. Lappin-Scott \& P. C. F. Oyston. Cambridge: Cambridge University Press.

Ventosa, A., Gutiérrez, M. C., Kamekura, M. \& Dyall-Smith, M. L. (1999). Proposal to transfer Halococcus turkmenicus, Halobacterium trapanicum JCM 9743 and strain GSL-11 to Haloterrigena turkmenica gen. nov., comb. nov. Int J Syst Bacteriol 49, 131-136.

Vreeland, R. H., Straight, S., Krammes, J., Dougherty, K., Rosenzweig, W. D. \& Kamekura, M. (2002). Halosimplex carlsbadense gen. nov., sp. nov., a unique halophilic archaeon, with three $16 \mathrm{~S}$ rRNA genes, that grows only in defined medium with glycerol and acetate or pyruvate. Extremophiles 6, 445-452.

Wainø, M., Tindall, B. J. \& Ingvorsen, K. (2000). Halorhabdus utahensis gen. nov., sp. nov., an aerobic, extremely halophilic member of the Archaea from Great Salt Lake, Utah. Int J Syst Evol Microbiol 50, 183-190.

Wilson, K. (1987). Preparation of genomic DNA from bacteria. In Current Protocols in Molecular Biology, pp. 241-242. Edited by F. M. Ausubel, R. Bent, R. E. Kingston, D. D. Moore, J. G. Seidman, J. A. Smith \& K. Struhl. New York: Wiley.

Xin, H., Itoh, T., Zhou, P., Suzuki, K., Kamekura, M. \& Nakase, Y. (2000). Natrinema versiforme sp. nov., an extremely halophilic archaeon from Aibi salt lake, Xinjiang, China. Int J Syst Evol Microbiol 50, 1297-1303.

Xu, Y., Zhou, P. \& Tian, X. (1999). Characterization of two novel haloalkaliphilic archaea, Natronorubrum bangense gen. nov., sp. nov. and Natronorubrum tibetense gen. nov., sp. nov. Int J Syst Bacteriol 49, 261-266.

Xue, Y., Fan, H., Ventosa, A., Grant, W. D., Jones, B. E., Cowan, D. A. \& Ma, Y. (2005). Halalkalicoccus tibetensis gen. nov., sp. nov., representing a novel genus of haloalkaliphilic archaea. Int J Syst Evol Microbiol 55, 2501-2505. 